\title{
A Duna-Tisza közi hátság szikes tavainak kilúgzási folyamatai a Szappanos-tó példáján
}

\author{
TóTH Tibor, MolnÁR Sándor, BALOG Kitti és BAKACSI Zsófia
}

MTA ATK Talajtani és Agrokémiai Intézet, Budapest

\section{Bevezetés}

A Duna-Tisza közi hátság az ország minden más területétől eltérő természetföldrajzi (elsősorban geomorfológiai, talajtani, biogeográfiai) sajátosságokkal rendelkezik (DöVÉNYI, 2010). Azok az ökológiai feltételek, amelyek korábban a természetes élőhelyek nagy kiterjedését és mozaikos elrendeződéséből következő nagyfokú diverzitását lehetővé tették, napjainkra radikálisan megváltoztak (BIRÓ et al., 2007; HOYK et al., 2007), hasonlóan egyéb alföldi területekhez (BAKACSI, 2001; HARMATI, 2000; RAKONCZAI et al., 2008; MARGÓCZI et al., 2009; LADÁNYI, 2010; LADÁNYI et al., 2012).

Az elmúlt több mint 30 évben a homokhátság területén a mezőgazdaság és a védett élőhelyek egyik legfőbb korlátozó tényezője a megfelelő mennyiségű és minőségü víz lett. A vízállásos területek a XX. század első felétől megkezdett lecsapolásával és a vízlevezetést szolgáló csatornázás nagymértékű kiterjesztésével végrehajtott térségi vízelvonás - az 1970-es évek elejétől észlelhető éghajlati szárazodással együtt - rendkívül kedvezőtlenül hatott a természeti környezetre és az élővilágra. A talajvízszint süllyedése a vizes élőhelyek kiszáradásához, sajátos jellegzetességeik elvesztéséhez és az élőhelyek egy részének pusztulásához vezetett (BIRÓ, 2011; BIRÓ et al., 2013). Egyes szikes tavak szinte a szemünk előtt tünnek el (BOROS \& BIRÓ, 1999). Emellett számos másik szikes tóban, de a mocsarakban és lápokban is jelentősen csökkent a vízborítás. A szárazabb környezetben a talajvíz átlagos szintje méterekkel süllyedt.

A síkvidéki területek vízháztartásában bekövetkezett változásokat legjobban a talajvízszint változása jelzi, ezért a térség problémáinak megoldásához a talajvízszint változásának vizsgálata, az arra ható tényezők mennyiségi és minőségi összefüggéseinek feltárása az egyik kiemelt fontosságú feladat (KOHÁN, 2014).

\section{A vizsgált terület földtani viszonyai}

A Duna-Tisza közi hátság, a Duna egykori hordalékkúpján alakult ki. Negyedidőszaki fejlődésében a folyóvízi feltöltés megszünését követően a Duna-völgy 
hordalékából kifújt eolikus üledékek lerakódása vált meghatározóvá (MOLNÁR, 1979).

A pleisztocén végi lerakódásokban a lösz és a futóhomok között folyamatos átmenetek vannak, azonban a rétegsort mindig a futóhomok zárja (1. ábra). Ezek az üledéktípusok adják a hátsági tavak bázisát (MOLNÁR, 1994). A tómeder képződése során a tóvízböl $0,2-0,8$ méter vastagságú karbonátiszap vált ki, amely vízszintesen sokszor csak lencsés kifejlődésű, de folytonos kifejlődés esetén nedvesen gyakorlatilag vízzáró réteget alkot (MOLNÁR, 1980).

A bócsai Szappanos-tó közvetlen környezetében a fúrások az üledéksorban legmélyebben aprószemü futóhomokot értek el. Erre 4-8 méter vastagságú lösz települt. A lösz alsó részén a kifejlődés típusos lösz, míg felső részén finom homokos lösz (FÉNYES \& KUTI, 1987).

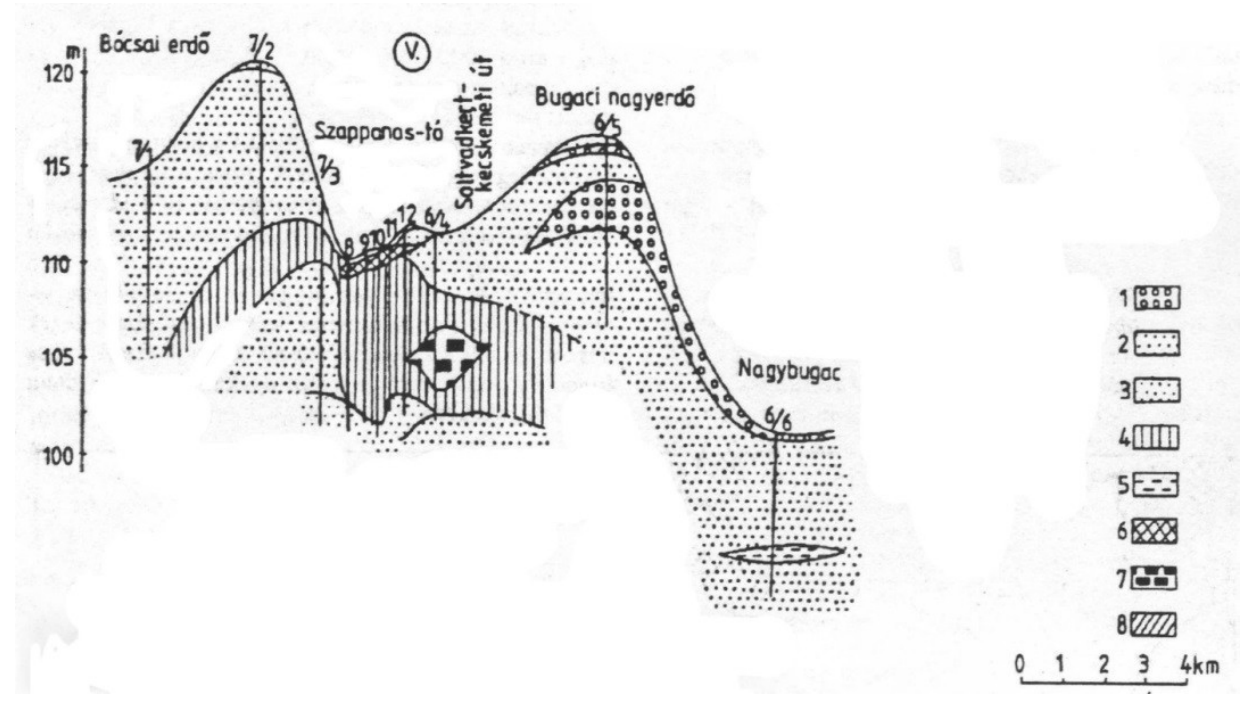

1. ábra

A Bócsa-bugaci területet és tavakat átszelő földtani szelvény (MOLNÁR \& KUTI, 1987). Jelmagyarázat: 1. Középszemü futóhomok, 2. Aprószemü futóhomok, 3. Finomszemü futóhomok, 4. Lösz (1-4. pleisztocén), 5. Tavi humuszos, rosszul osztályozott kőzetliszt, 6. Karbonátiszap (5-6. holocén), 7. Tőzeg (pleisztocén-holocén), 8. Humuszos rétegek a felszínen

A löszre többször aprószemü, jelentős karbonát-tartalmú (>10\%) futóhomok települt. Az üledéksort nagy kiterjedésü, maximum $50 \%$ karbonát-tartalmat elérő karbonátiszap és a felszínen talajosodott, humuszos, áthalmozott futóhomok zárja.

\section{A vizsgált terület vízrajzi viszonyai}

A felszínen a folyóvizek szerepe alárendelt, azonban a lefolyástalan medencékben jelentős méretü tavak alakultak ki. A nagyobb tavakon kívül nagyon sok, egy- 
mástól kisebb háttal elválasztott mocsár, vízállásos terület volt elszigetelődve, amelyek - a tavaszi idojjárásnak megfelelöen - hol kisebb, hol nagyobb vízfelülettel rendelkeztek (BUZETZKY \& ZSUFFA, 1979).

A hátság vízháztartásának legfőbb bevételi forrása a csapadékból származó vízmennyiség. Ezt a különböző vízhasználatok kibocsátása (tisztított szennyvizek), valamint a Dunából és a Tiszából öntözővízként kiemelt vízmennyiség egészíti ki. A vízhiányos, gyakran szélsőségesen száraz állapotot a homok erős és gyors felmelegedése és nagy hőkisugárzó képessége tovább erösíti (КOHÁN, 2014).

A bócsai Szappanos-tó a Tisza vízgyüjtőjében fekszik. A területén áthaladó Bócsa-Bugaci-csatorna a tó vizét a Dong-éri-föcsatornába vezeti. A fölös, környezetre veszélyes túlduzzadását az elvezető csatornába épített esésnövelö szivattyútelep is mérsékli (BUZETZKY \& ZSUFFA, 1979).

\section{A vizsgált terület talajvizeinek jellemzése}

A Duna-Tisza közi hátságon a talajvízszint tengerszint feletti magassága többnyire jól követi a talajfelszín lejtését (CSERNI \& FÜLEKY, 2008). A laposokban és az egykori tavak helyén a felszínhez közelebb, átlagosan egy-két méter mélyen húzódik. A nagy vastagságú, homokkal borított területeken általában mélyebben, körülbelül négy méter mélységben található (KERÉK, 2003). A talajvíz-tükör lejtése a vízválasztótól mind a Duna, mind a Tisza irányába nagy.

Az Országos Vízügyi Főigazgatóság talajvízfigyelő kúthálózatának adatai szerint az 1990-es évek közepére a Duna-Tisza köze magasabban fekvő területein a talajvízszint átlagosan 250-300 cm-rel mélyebbre süllyedt az 1956-1960 közötti bázisidőszak átlagához viszonyítva. Eközben a peremi területeken lényegesen kisebb volt a süllyedés, sőt egyes térségekben a változások nem tekinthetők számottevőnek (PÁLFAI, 1995; KUTI et al., 2002b; SZALAI, 2004). A talajvíz nagyobb mértékủ süllyedését több tényező együttesen okozhatja, többek között a tartós csapadékhiány, a felszín alatti vízkészlet kitermelése, az erdősítés és az összegyülemlö vizek többnyire szabályozatlan elvezetése (SzALAI et al., 2012).

A 2000-es évek második felében az észlelőkutak többségében a talajvízszint süllyedése tovább folytatódott, amit a 2004-2006 közötti csapadékosabb időszak és a 2010-es év rekord mennyiségü csapadéka tudott csak némileg ellensúlyozni. 2011-ben és 2012-ben a meteorológiai helyzet ismét nem alakult kedvezően, így újra süllyedés volt tapasztalható (SZALAI, 2012).

A Duna-Tisza közi hátság talajvizei többnyire kalcium-hidrogénkarbonátosak, jelentős területen vannak azonban magnézium-hidrogénkarbonátos vizek is. A buckák közötti szikes laposokban nátrium-hidrogénkarbonátos vizek fordulnak elő (KUTI et al., 2002a).

\section{A vizsgált terület talajtani viszonyai}

A bócsai terület talajainak kialakulásában a talajképződési tényezők közül a talajképző kőzetnek, valamint a domborzati- és vízviszonyoknak van kiemelt jelentősége. A talajviszonyok többnyire követik a domborzati formákat. 
A felszínközeli finomabb szemcseeloszlású rétegek jól tartják a vizet és bennük a kapilláris-emelkedés feltétele is kedvezőbb, ezért a homokterületen a párolgás okozta vízveszteség utánpótlása gyorsabb.

A domborzati mikroformák és a különbözö települési viszonyok azonban a terület mikroheterogenitását növelik, amit a növényasszociációk változatos megjelenési formája is tükröz (VÁRALLYAY et al.,1983).

A buckacsoportok, homokhátak talajainak fejlödési vonalát elsősorban a szerves anyag felhalmozódása határozza meg. Ez alapján a futóhomok $\rightarrow$ humuszos homok $\rightarrow$ csernozjom jellegü homok fejlődési sor állítható fel. Ezzel szemben a lapályokon és buckaközi mélyedésekben a felszínközeli, helyenként jelentősen sós és magas szódatartalmú vizek hatására hidromorf talajok jöttek létre. A láptalaj $\rightarrow$ lápos-réti talaj $\rightarrow$ réti talaj hidromorf sorban a nátrium sók hatására elsősorban szoloncsákos, néhol pedig szolonyeces változatok is előfordulnak. A hidromorf talajokat gyakran a környezö buckákról származó lepelhomok fedi (RAJKAI et al., 1983; VÁRALlYAY, 1993).

A réti talajok, ha a víz elfolyása folyamatos, nem szikesednek el. Amennyiben a felszíni víz nem tud elfolyni, a helyszínen töményedik be és lassan szivárog a talajba. Csapadékosabb időjárás esetén a talajvíz szintje szintén emelkedik. A beszivárgás és bepárlódás ismétlődése miatt a lefolyástalan medencék felszíni vizeinek sótartalma állandóan növekszik, ezért a talaj sótartalma is növekedni fog. A vizek magas nátrium-hidrogénkarbonát tartalma pedig szikesedést okoz. Attól függően, hogy a sók a talajszelvényben hol halmozódnak fel, különböző szikes talajok keletkeznek (SZABOLCS \& JASSÓ, 1961). A terület vízforgalmi viszonyainak megváltozása - amint a következőkben bemutatjuk - ezt a sémát jelentősen módosítja.

\section{A kilúgzási modell}

Az elmúlt évtizedek folyamán jelentős hidrológiai változások mentek végbe a térségben, melynek a területre vonatkozó, regionális víz- és sóforgalmat befolyásoló aspektusait számos közlemény tárgyalta (ERDÉLYI, 1979; VÁRALLYAY, 1993; MÁDLNÉ SZÖNYI et al., 2005, 2008); ezeket a modell alkotás során figyelembe vettük (2. ábra, 1. táblázat). A megjelent közlemények a szikes tavak kilúgzásáról számolnak be (BOROS \& BIRÓ, 1999; HOYK et al., 2009). Regionálisan nem áll rendelkezésre megfelelő térbeli felbontással a talajok sóforgalmára vonatkozó talajtani adat, és igen érdekes kérdés az is, hogy a szikes tavakra jellemző, korábban nagy sótartalmat okozó só vajon hol van.

A 2. ábrán és az 1. táblázatban jelzett folyamatok közül a csökkenő csapadékmennyiség a felszínközeli kilúgzás gyengülése miatt okoz növekvő talajsótartalom változást. A felszínközeli beszivárgás (recharge) gyengülése csökkenő mennyiségü, megnövekedett sótartalmú talajvíz feláramlással (discharge) jár együtt, emiatt okoz csökkenő talajsótartalmat (TóTH, 2009). A párolgás növekedése jelentősebb felfelé irányuló oldatmozgást okoz, ami a sófelhalmozódásnak kedvez. 


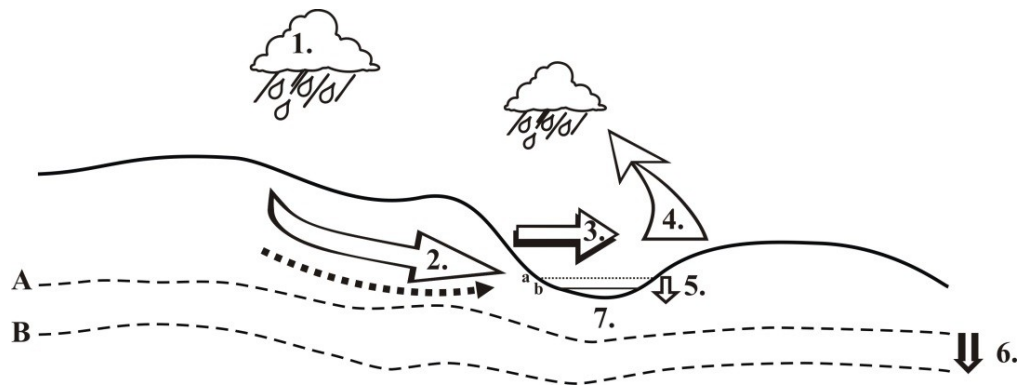

\section{2. ábra}

A hátsági (regionális) koncepcionális vízforgalmi modell egy szikes tó tágabb környezetében. Jelmagyarázat: A. Talajvízszint az 1960-as években, B. Talajvízszint napjainkban.

a) Tóvízszint az 1960-as években, b) Tóvízszint napjainkban.

(A számokkal jelzett folyamatokat az 1. táblázat tartalmazza)

\section{1. táblázat}

A 2. ábrán jelzett folyamatok összefoglalása az 1960-as évektől napjainkig

\begin{tabular}{|c|c|c|c|}
\hline Azonosító & $\begin{array}{c}\text { (1) } \\
\text { Tényező, folyamat }\end{array}$ & $\begin{array}{c}\text { (2) } \\
\text { Vízmennyiség } \\
\text { alakulása }\end{array}$ & $\begin{array}{l}\text { (3) } \\
\text { Talajsótartalom } \\
\text { változás a tó } \\
\text { környezetében }\end{array}$ \\
\hline $\begin{array}{l}1 \\
2 \\
3 \\
4 \\
5 \\
6\end{array}$ & $\begin{array}{l}\text { a) Téli csapadék mennyisége } \\
\text { b) Felszín alatti oda/beszivárgás } \\
\text { c) Csatorna müködése } \\
\text { d) Párolgás } \\
\text { e) Tóvízszint } \\
\text { f) Talajvízszint } \\
\text { g) Tófenéki mésziszap vízát- } \\
\text { eresztő jellege }\end{array}$ & $\begin{array}{l}\text { h) Csökken } \\
\text { h) Csökken } \\
\text { i) Vízelvezetés } \\
\text { j) Nő } \\
\text { h) Csökken } \\
\text { k) Süllyed* } \\
\text { l) Kiszárad, } \\
\text { feldarabolódik, } \\
\text { áteresztővé válik }\end{array}$ & $\begin{array}{l}\text { Nő } \\
\text { Csökken } \\
\text { Csökken } \\
\text { Nö } \\
\text { Nő } \\
\text { Csökken } \\
\text { Csökken }\end{array}$ \\
\hline
\end{tabular}

Megjegyzés: *A talajvízszint változására a mélységi vízkivétel és az erdősítés növekedése miatt megnőtt talajvízfelvétel is hatással van (КоHÁN, 2014), de ezt külön nem jelöltük.

A tó vízszintjének csökkenése a tóvízben oldott anyagok feldúsulásával jár együtt, s azok talajba szivárgása nagyobb sótartalmat okoz.

A talajvízszint süllyedése - a ,kritikus mélység” (KovDA et al., 1973) alá hosszabb távon a sós oldatok és a talajfelszín közötti kölcsönhatás csökkenését, sós talajvíz esetén csökkenő talajsótartalmat eredményez. A mésziszap töredezése segíti a tóban összegyült csapadék kilúgzó hatásának érvényesülését.

A felszíni sótartalom-változás értelmezéséhez a szikesedéssel kapcsolatban számba vehető összes terepen vizsgálható paramétert számszerüsíteni kívántuk.

Azt a célt tüztük ki, hogy megvizsgáljuk a talaj szikesedését befolyásoló tényezőket, mindenekelőtt a talajvizet, annak mélységét és összetételét. 
Összevetettük a 2014-es felvételezés eredményeit az 1983-as adatokkal, majd térben és időben is érvényes koncepcionális modellt állítunk fel a sótartalom csökkenésére (kilúgzásra).

A modell alapján azt vártuk, hogy a talajvíz szintje napjainkra a korábban észleltnél mélyebben helyezkedik el, és a talajvíz valamint a talaj sótartalma a korábbihoz képest jelentősen alacsonyabb lesz (3. ábra).
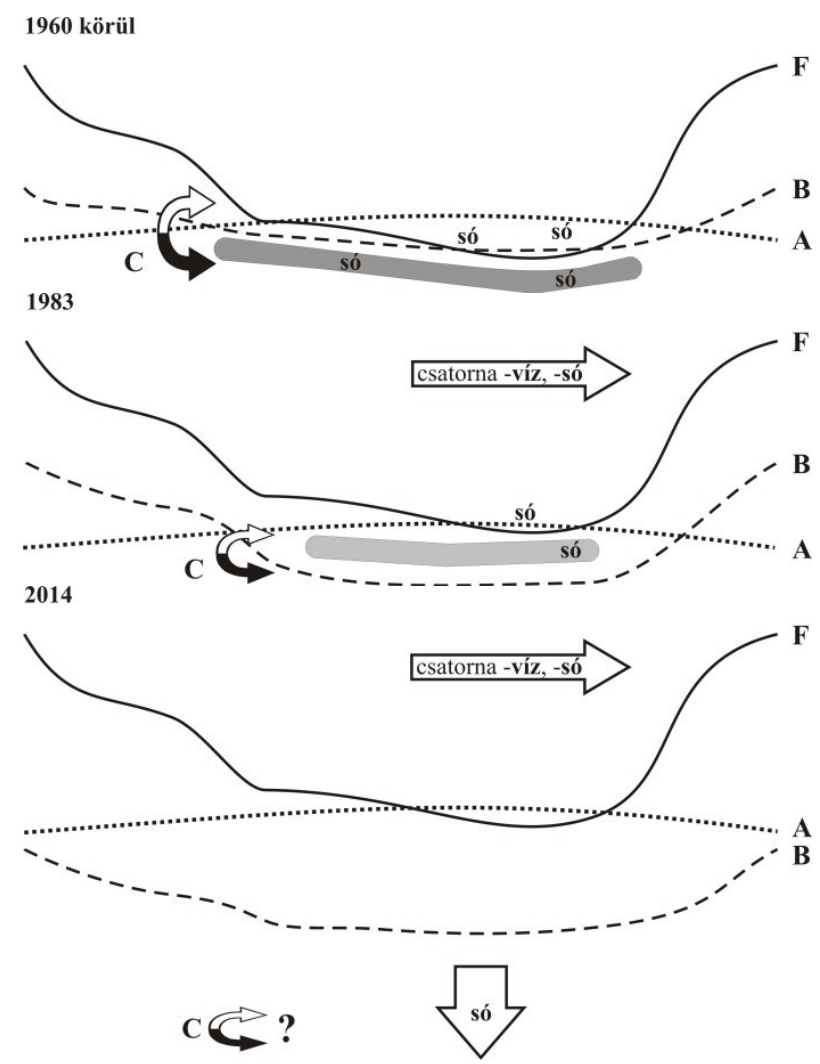

3. ábra

A tavi (lokális) modell a bekövetkezett hidrológiai változások sematikus feltüntetésével. Jelmagyarázat: A. Talajvízszint a csapadékos időszak után, B. Talajvízszint a regionális vízgyüjtőről származó beszivárgás/hozzáfolyás után, C. Sófelhalmozódás, a sóknak a talajvíz és a talaj közötti kicserélödése, F. Talajfelszín

\section{Anyag és módszer}

A talaj/altalaj és a talajvíz sótartalom változásának értékelését az 1983-ban vizsgált helyeken (VÁRALLYAY et al., 1983), azonos módszerrel megismételve végeztük el. 
VÁRALLYAY és munkatársai 1983-as, a Duna-Tisza közi hátság termőhelyi viszonyaival foglalkozó beszámolójának áttanulmányozása után a mintaterületek közül kiválasztottuk a Szappanos-tavat - mint a leginkább megfelelő példát a homokhátsági szikes tavakban lejátszódó folyamatok bemutatására. A helyszín ideális, mert a mintavételi pontok már az 1983-as vizsgálat során is lefedték a legjellegzetesebb tómeder szakaszokat a tó fenekétől egészen a partjáig.

A vizsgálati pontok azonosítása után az MTA ATK TAKI Térképtárában megtaláltuk a korabeli terepi vizsgálatokhoz használt térkép másolatát, amelyen a Szappanos-tó és a négy mintavételi pont helyét bejelölték. A jellegzetes terepi helyszínek azonosítása után térinformatikai rendszerbe helyeztük a pontokat és így azok földrajzi koordinátákat kaptak; az azonosítás mintegy \pm 30 méteres pontossággal történt. Annak érdekében, hogy az egyes pontok kijelölésében jelentkező pontatlanság hatását csökkentsük, a teljes - medertöl peremig felvett - transzektet megmintáztuk. Az értékelésben nem csupán a mintavételi helyek, hanem a transzekt változását is értékeltük.

A terepi vizsgálatok során (2014. november 25-én) a következő felvételezést végeztük el:

I) A terepi pontok kijelölése. Az 1983-as mintavételek helyén elektromágneses indukciós szondával kiválasztottunk egy mintegy 20 m átmérőjü homogén foltot, itt végeztük el a talajmintavételt.

II) A helyszínen rögzítettük a legfontosabb növényfajokat és fúrást végeztünk kettős céllal; egyrészt a laboratóriumi vizsgálatokhoz szükséges talajmintákat gyüjtöttük be (0-120 cm-ig $10 \mathrm{~cm}$-enként és $120 \mathrm{~cm}$ alatt $20 \mathrm{~cm}$-enként), másrészt meghatároztuk a talajvíz megütési és nyugalmi szintjét, illetve a talajvízből elemzéshez mintát vettünk. A 26-os ponton a felszínen álló vízből is vettünk mintát.

III) A vizsgálati pontok magasságát szintezéssel meghatároztuk és átszámítottuk abszolút magassággá.

A vizsgált minták leírásával kiegészítve elkészítettünk egy szelvény (ez esetben fúrás) leíró lapot olyan formátumban, mint ahogy az 1983-ban történt. Leírtuk a talajrétegek színét, szemcseösszetételét, szerkezetét, karbonátosságát, gyökértartalmát és kiválásait.

Laboratóriumi elemzéseinkkel a már 1983-ban is dokumentált talajparamétereket jellemeztünk. 1:2,5 talaj:desztillált víz szuszpenzióban egy napos állás után megmértük a szuszpenzió elektromos vezetőképességét (ebből később két lépéses becslés után a só\%-ot határoztuk meg, az 1983-as adatokkal való összevethetőség érdekében), a pH-t és a pNa-t (a $\mathrm{Na}$ mólkoncentráció negatív logaritmusa) ionszelektív elektróddal. Meghatároztuk a talaj $\mathrm{CaCO}_{3}$ tartalmát Scheibler-féle kalciméterrel, a humusztartalmát pedig Tyurin módszerével. A talaj szemcseösszetételének jellemzésére a Sik-féle higroszkóposság értéket (hy $\left.{ }_{1}\right)$ használtuk.

Ez alapján a FILEP és FERENCZ (1999) által közölt táblázat szerint a higroszkóposság és az Arany-féle kötöttség (KA) között összefüggést állítottunk fel.

ILACO (1981) módszere alapján számítottuk a kötöttségi paszta talajoldatának elektromos vezetőképességét. Ezt az értéket a talajpaszta vezetőképességével egyezőnek feltételeztük, és az MSz 08-0206/2:1978 táblázatának adataira illesztett öszszefüggés alapján becsültük a 2014-ben gyüjtött talajminták sótartalmát. 
A gyüjtött öt vízminta (négy talajvíz és egy felszíni víz) kation $\left(\mathrm{Na}^{+}, \mathrm{K}^{+}, \mathrm{Mg}^{2+}\right.$, $\mathrm{Ca}^{2+}-\mathrm{ICP}$ analízis) és anion $\left(\mathrm{HCO}_{3}{ }^{-}, \mathrm{CO}_{3}{ }^{2-}-\right.$ titrálás; $\mathrm{Cl}^{-}, \mathrm{SO}_{4}{ }^{2-}-\mathrm{ICP}$ analízis $)$ összetételét, vezetőképességét és pH-ját is meghatároztuk.

A harmincegy év alatt végbemenő változások értelmezéséhez a meder domborzatának megfelelően felrajzoltuk a vizsgálati paraméterek mélységi grafikonjait és a görbelefutásokat összehasonlítottuk. Mind a medren belüli lefutásokat, mind a 31 év során tapasztalt görbe elcsúszásokat értékeltük. Mivel VÁRALLYAY és munkatársai (1983) szelvénygödrökben vették a talajmintákat és az értékeket genetikai szintekre adták meg, az 1983-as és 2014-es görbék lefutása nem hasonlítható össze mindegyik mélységben.

\section{Eredmények}

A Bócsai területen, a Szappanos-tó száraz fenekén és környékén a szikes talajok különböző típusai (szoloncsák, szoloncsák-szolonyec és réti szolonyec) fordultak elő az 1983-as vizsgálatok idejében (2. táblázat).

A talajvíz sótartalma és sóösszetétele szoros összefüggést mutatott a szikes talajok tulajdonságaival, a szelvény felépítésével, morfológiájával. A szikesedést elöidéző talajvizek oldható sókészlete igen nagy volt, és helyenként időben is változott.

A talajban és a talajvízben lévő sókészlet $\mathrm{NaHCO}_{3}$ és $\mathrm{Na}_{2} \mathrm{CO}_{3}$ típusú volt. A talajszelvényben sósav hatására a felszíntől a talajvízszintig élénk pezsgés volt tapasztalható, ami a kalcium-karbonátban gazdag alapkőzet és a talajvízből történő kiválási-felhalmozódási folyamatok együttes következménye volt.

\section{2. táblázat}

A talajtípus, a növényzet és a humusztartalom az 1983-as és a 2014-es felvételezéskor

\begin{tabular}{|c|c|c|c|c|}
\hline \multirow{2}{*}{$\begin{array}{l}\text { (1) } \\
\text { Mintavé- } \\
\text { teli pont }\end{array}$} & \multicolumn{2}{|c|}{$\begin{array}{l}(2) \\
\text { Év }\end{array}$} & \multicolumn{2}{|c|}{$\begin{array}{c}(3) \\
\text { Humusztartalom, \% } \\
(0-10 \mathrm{~cm} / 10-20 \mathrm{~cm})\end{array}$} \\
\hline & 1983 & 2014 & 1983 & 2014 \\
\hline $26 .^{*}$ & $\begin{array}{l}\text { a) Szódás } \\
\text { szoloncsák/Nád, káka, } \\
\text { szittyó }\end{array}$ & $\begin{array}{l}\text { e) Réti talaj/Nád, Tarac- } \\
\text { kos tippan, Zsióka }\end{array}$ & $1,3 / 1,0$ & $3,5 / 1,5$ \\
\hline 14. & $\begin{array}{l}\text { b) Szoloncsák/ } \\
\text { Sziki sóballa }\end{array}$ & $\begin{array}{l}\text { f) Réti talaj / Sovány } \\
\text { csenkesz, moha, Nád } \\
\text { elszórva }\end{array}$ & $1,1 / 0,78$ & $3,8 / 1,4$ \\
\hline $14 a$. & $\begin{array}{l}\text { c) Lepelhomokkal fedett } \\
\text { szoloncsákos réti talaj/ } \\
\text { Sziki mézpázsit }\end{array}$ & $\begin{array}{l}\text { g) Réti talaj /Tarackos } \\
\text { tippan, Réti ecsetpázsit, } \\
\text { Nádak, Sziki cickafark }\end{array}$ & $0,36 / 0,24$ & $11,1 / 5,5$ \\
\hline $21 . * *$ & d) Réti talaj/Rét & $\begin{array}{l}\text { h) Réti talaj /Sovány } \\
\text { csenkesz, moha, Sziki } \\
\text { cickafark }\end{array}$ & $3,6 / 3,6$ & $6,4 / 1,7$ \\
\hline
\end{tabular}

Megjegyzés: * Meder; ** Tópart 
A

Szappanos-tó mintavételi helyek

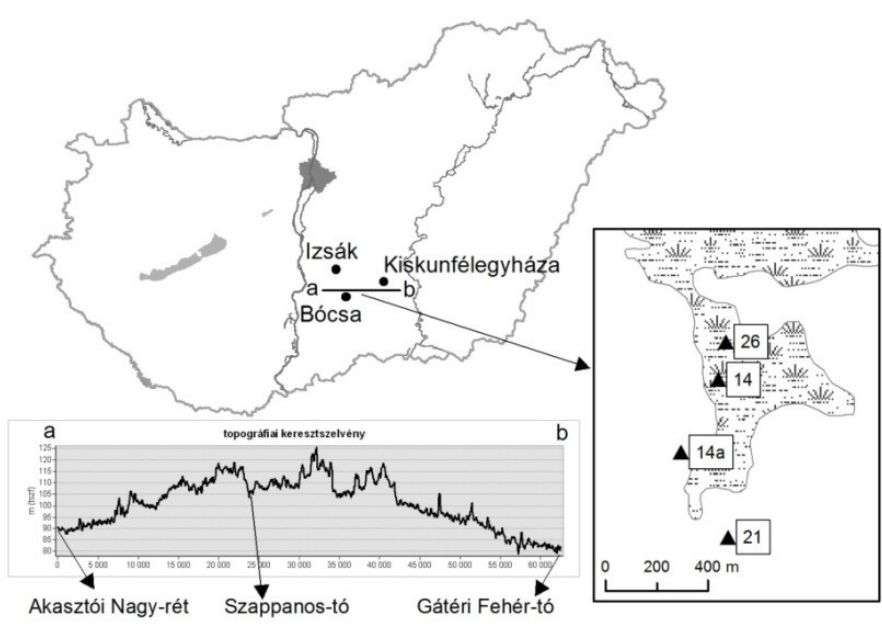

26

14

$14 \mathrm{a}$

21

\section{B}
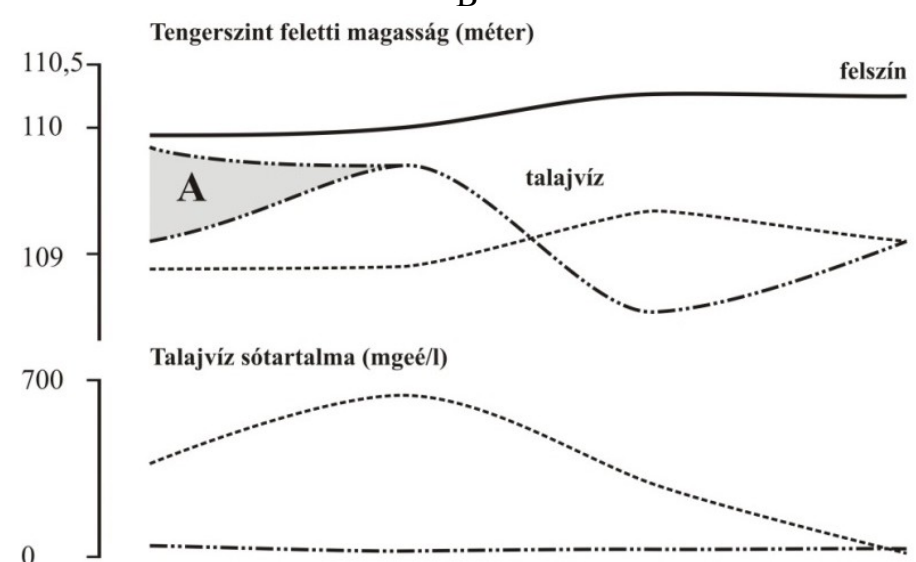

0,6

Talaj sótartalma 60 és $100 \mathrm{~cm}$ között (\%)

0

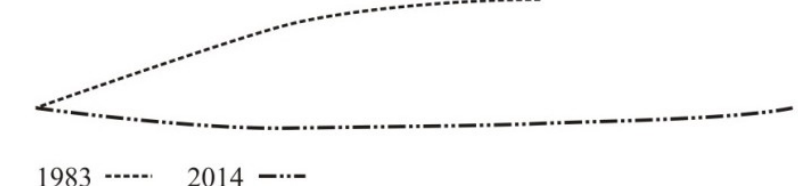

4. ábra

(A) A vizsgált tó és a vizsgálati pontok elhelyezkedése, illetve (B) a talajvízszint valamint a talajvíz- és a talaj sótartalmának változása a 1983-as és a 2014-es felvételezés alapján a meder és tópart között kijelölt azonos pontokban. „A”-val a 2014-es felszíni víz és talajvíz közötti keveredés miatti mérési bizonytalanságot jelöltük 
A területen a szikes talajok kialakulásával kapcsolatban tehát három fontos részfolyamatot szükséges megemlíteni. Az uralkodó szikesedési folyamat a szódásszoloncsák talajképződés volt. Emellett jelen volt a szolonyec talajképződés és azok átmenetei, valamint mészakkumulációs folyamatok is zajlottak (VÁRALLYAY et al.,1983).

A talajvízszint és -összetétel változása a transzekt mentén minden paraméterben a fordítottjára változott az elmúlt 31 évben. A megütött talajvízszint változása valószínűtlenül alakul: a 2014 évi szint rögzítése a tómeder közepi pontban a fúrás közben beszivárgó felszíni víz miatt bizonytalan volt, ezen felül a mintavétel elötti csapadékos időszak, illetve a 1983-ban a száraz augusztusi idő és a 2014-es hűvös és nedves novemberi idő közötti különbség is szerepet játszik a mért értékek alakulásában (4. ábra). Valószínüleg a 2014-es évi csapadékos ősz miatt a talajvíz sekélyebben helyezkedett el a két belső pontban, mint 1983-ban. Ugyanakkor a tó pereméhez közeledve mintegy $80 \mathrm{~cm}$-rel mélyebben találtuk a talajvizet, a tavon kívül eső pontban pedig ugyanabban a mélységben találtuk a talajvizet, mint 31 éve.

A talajvizek sótartalmának összehasonlítása igen erősen jelezte a bekövetkezett felszíni sótartalom csökkenést (4. ábra). Az összes sótartalom általában két nagyságrenddel csökkent, míg a tómedertől legtávolabbi pontban (21.) kismértékben növekedett. Így a transzekt mentén a talajvíz sótartalmának kiegyenlítődése figyelhető meg.

Míg a tó közepén és szélén lévő pontokban (26., 14. és 14a.) jelentősen - kevesebb, mint 1/9 részére - csökkent a talajvíz sótartalma, a tóparton mintegy kétszeresére nőtt.

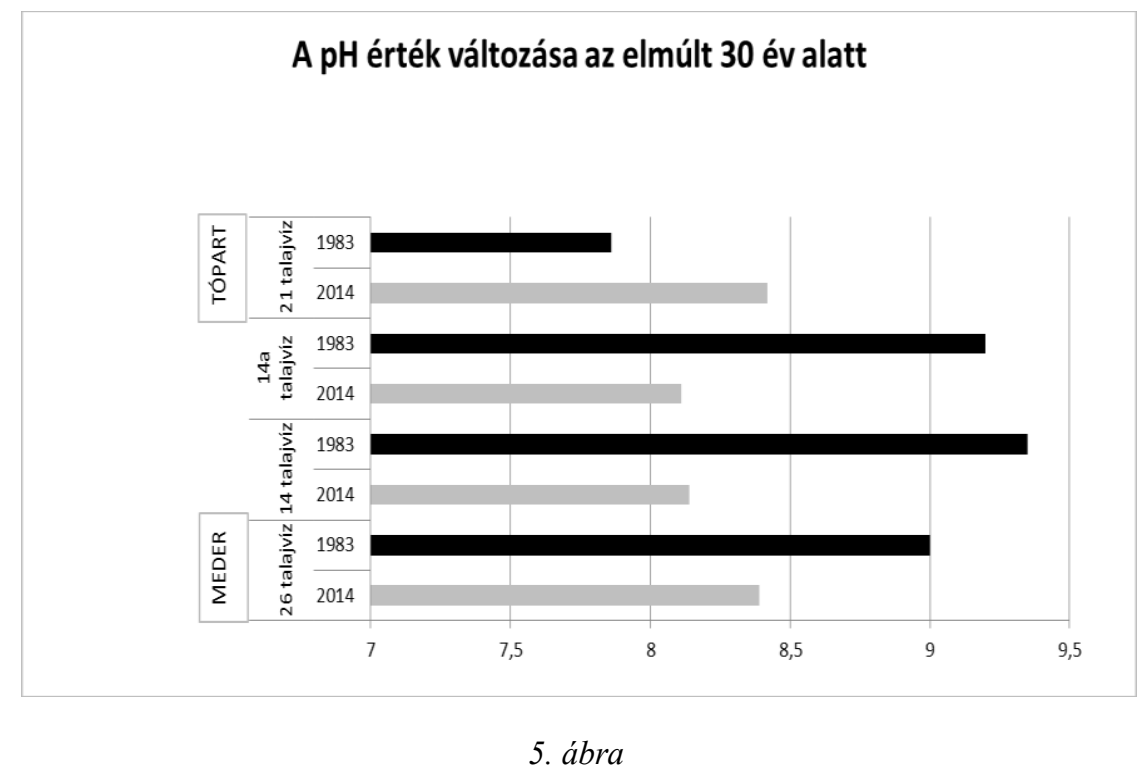

A talajvíz pH-értéke a 1983-ban és 2014-ben a tómeder és a tópart között elhelyezkedő pontokban 
A kationok között a $\mathrm{Na}^{+}$eredeti domináns szerepe csökkent, a $\mathrm{Mg}^{2+}$-é viszont nőtt. $\mathrm{A} \mathrm{Na}^{+}$rovására a $\mathrm{Ca}^{2+}$ részaránya is növekedett az egykori meder mintavételi pontjai esetén, ami a talajvíz minőségi javulását, szikesítő hatásának csökkenését idézte elö. Az anionok mennyisége összességében csökkent (párhuzamosan a sótartalom csökkenéssel), s ezen belül is a lúgosító $\mathrm{CO}_{3}{ }^{2-}$ és $\mathrm{HCO}_{3}{ }^{-}$mennyiségi csökkenése emelhető ki. Ennek ellenére a $\mathrm{HCO}_{3}{ }^{-}$még mindig domináns anion a többi vizsgált anionhoz képest. A pH-érték is mindenhol csökkent a meder területén, így az erősen lúgosból a lúgos tartományba került át., míg a tóparton a pH-érték nőtt, így a teljes transzekt esetében a kémhatás kiegyenlítődését figyelhetjük meg (5. ábra).

A talajok sótartalom-csökkenése (4. és 6. ábra) egyértelmüen megnyilvánult a 14. és 14a. szelvények esetében. A 26-os pont esetében hasonló értékeket találtunk, mint 31 éve. A 21. pont sótartalmát a növényzet és a térszíni helyzet alapján alacsonynak vélték, ezért 1983-ban nem mérték. A sótartalom 2014-ben a felszínen megközelítette a szikes talajok határértékét, a $0,1 \%$-ot, de nem lépte át azt, és csak $80 \mathrm{~cm}$ alatt, a tó közepén és partján mértünk 2014-ben viszonylag nagyobb sótartalom értéket $(0,4 \%<)$.

A pH-értékek a sótartalomhoz hasonlóan változtak, azt mutatják, hogy a felszín alatt 80-100 cm-es mélységben a 26 . és 21 . pontokban a pH eléri a 9,5-ös, erösen lúgos értéket (7. ábra). A sótartalom és a $\mathrm{pH}$ legnagyobb mértékủ csökkenését a 14a. pontban tapasztaltuk. A talajok pNa értékének mélységi eloszlása nagyjából megegyezett a sótartalom görbéjével. Ez alapján enyhe (nátriumos) sófelhalmozódást mutathatunk ki közvetlenül a felszín közelében, és egy másikat 100 cm-es mélységben.

Szappanos-tó mintavételi helyek

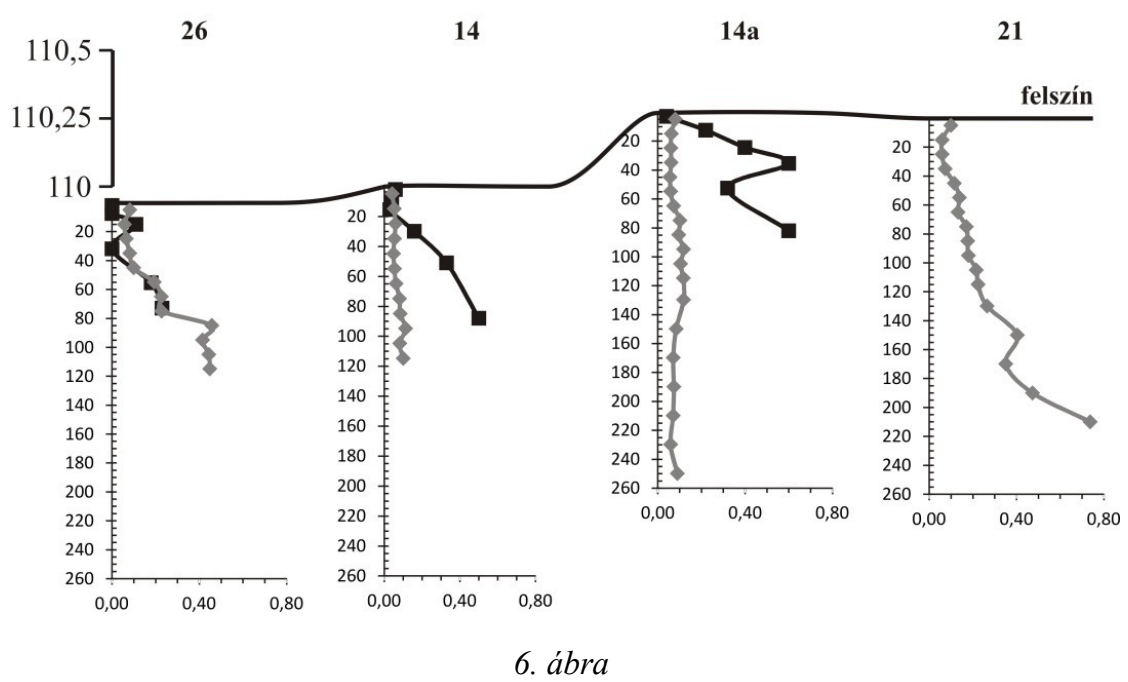

A sótartalom (\%) változása a tengerszintfeletti magasság alapján rendezett szelvényekben. A fekete vonalak az 1983-as (mért), a szürke vonalak a 2014-es (vezetőképességböl számított) felvételezés értékeit mutatják 


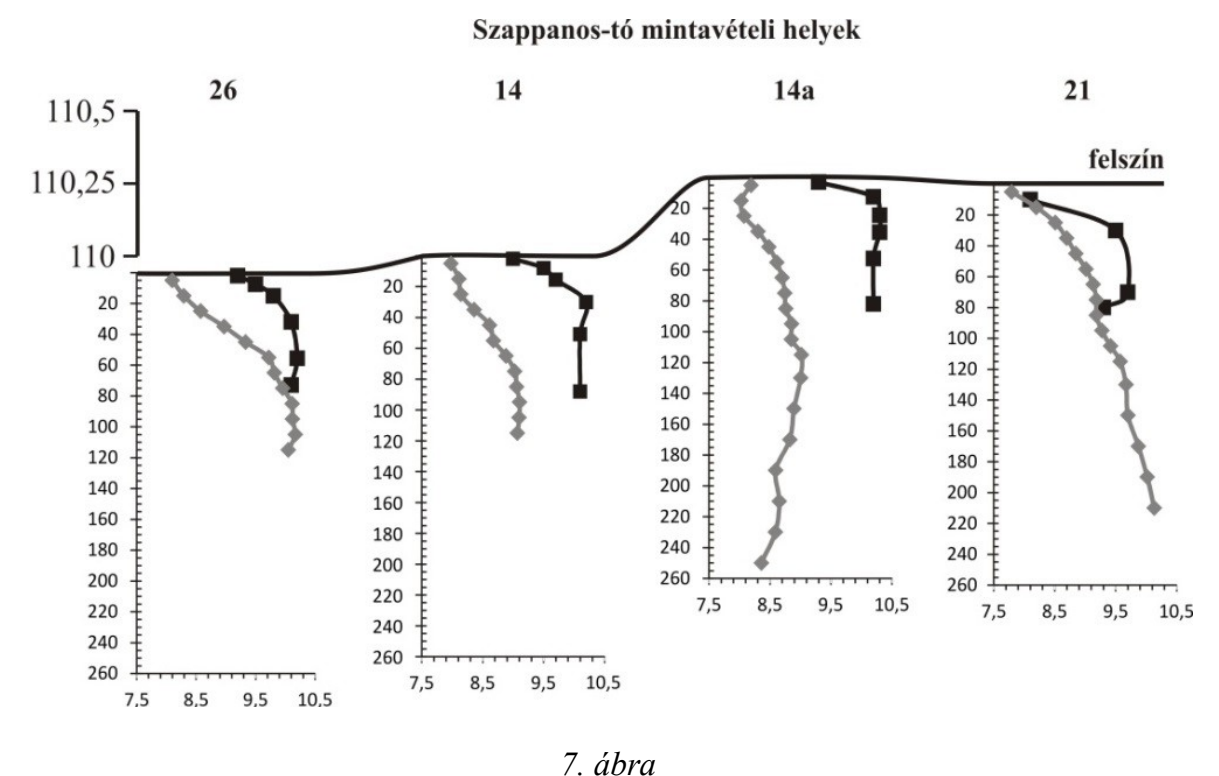

A pH változása a tengerszintfeletti magasság alapján rendezett szelvényekben. A fekete vonalak az 1983-as, a szürke vonalak a 2014-es felvételezés értékeit mutatják.

Ezek a változások arra utalnak, hogy a felszínközelből a só mélyebb rétegekbe került, de a talajvíz jelentösebb mennyiséget a felszín közelébe nem emel. Ennek oka a döntően lefelé irányuló vízmozgás lehet. A kilúgzással összefüggésben a területen a növények számára kedvezőbb életfeltételek jöttek létre, emiatt teljes növényi borítást tapasztalunk, nem tipikusan sótürö növények előfordulásával együtt. Ha a sekély talajvíz a felszín közelébe emelkedik, a zárt növényfelszín miatt a talajfelszínre nem kerül só, mert egyrészt a felszín árnyékolt és nincs erös talajfelszíni párolgás, másrészt a felhígult talajvíz alacsony sótartalma nem jelent számottevő veszélyt a felszíni sófelhalmozódás szempontjából.

A tó alatti kilúgzásra vonatkozó adataink alátámasztják az elsődleges elképzeléseinket (3. és 4. ábra), és egyeznek LADÁNYI (2010) illetve LADÁNYI és munkatársai (2012) tapasztalatával. A 4. ábra talajvízszintje az 1983. évben megfelel a 3. ábra B talajvízszintjének, mivel nyári időszakban történt a vizsgálat. A 2014. év során tapasztaltak (4. ábra) pedig megfelelnek a 3. ábra A talajvízszintjének, mivel egy esős őszi időszak után végeztük a felvételezést. A nyár végi legmélyebb talajvíz szint és felszín alatti sótartalom alakulását jelenleg vizsgáljuk.

A talajvíz és talaj sótartalma mind a két vizsgálati évben megfelel a 3. ábrán bemutatott sémának. A meteorológiai viszonyokat tükröző, évről évre ingadozó talajsótartalom (KovÁCs et al., 2006) elsősorban a legalacsonyabb helyzetű mintapontokban figyelhető meg, az ingadozó vízmennyiség és az ennek megfelelő leszivárgás-kilúgzás, illetve párolgás-kapilláris vízemelés miatt.

Viszonylagos állandóságot tapasztaltunk azonban a tóparti mintapont (21.) esetében a talajvízszint, a kémiai tulajdonságok és a pH-értékekben (7. ábra) is. 
A pH állandósága alapján feltételezzük a sótartalom állandóságát is. Ebben a pontban a megütött talajvízszint, a talajtípus és a növényzet sem mutatott változást.

Tapasztalataink szerint a tájból a só nem tủnt el. 2200 méterrel délre, hasonló magasságban elhelyezkedő,1983-ban még szántóként müvelt talajfoltban (TóTH et al., 2014) a tó alatt mérteknél jelentősen nagyobb sótartalmakat tapasztaltunk a mélyebben (3-4 m) megütött talajvízben. A talajvízben mért elektromos vezetőképesség és megütött talajvíz mélység értékek a Szappanos-tóval összehasonlítva a következök voltak.: Szappanos-tó pontok: 26 . pont $\left(1,9 \mathrm{mS} \cdot \mathrm{cm}^{-1}-0,6 \mathrm{~m}\right), 14$. pont $\left(1 \mathrm{mS} \cdot \mathrm{cm}^{-1}-0,4 \mathrm{~m}\right), 14 \mathrm{a}$. pont $\left(1,5 \mathrm{mS} \cdot \mathrm{cm}^{-1}-2 \mathrm{~m}\right), 21$. pont $\left(1,3 \mathrm{mS} \cdot \mathrm{cm}^{-1}-1,4\right.$ $\mathrm{m})$; erdészeti monitoring pontok: rét $\left(1,7 \mathrm{mS} \cdot \mathrm{cm}^{-1}-3 \mathrm{~m}\right)$, szürkenyár-ültetvény $(2,7$ $\left.\mathrm{mS} \cdot \mathrm{cm}^{-1}-3 \mathrm{~m}\right)$, erdeifenyö-ültetvény $\left(4,6 \mathrm{mS} \cdot \mathrm{cm}^{-1}-4 \mathrm{~m}\right)$. Ez arra utal, hogy a korábban felszínközeli talajvízből a feltalajban történt sófelhalmozódás feltételeinek megszüntével a sófelhalmozódás a felszín alatti rétegekben játszódik le. Ennek speciális esete az erdő jelentősen nagyobb talajvízfelvétele miatt az erdő alatt tapasztalt (a rét alattihoz képest) nagyobb sófelhalmozódás (TóTH et al., 2014). Más szóval a talajvíz szikesítő képessége oldott anyag tartalma következtében továbbra is megvan, és megfelelő feltételek mellett a sófelhalmozódás folyamata megfigyelhetö.

Az eltelt 31 év alatti változásokat a karbonáttartalom mélységi görbéi jól jellemzik (8. ábra). Az 1983-ban jellemző, a tómederben 109,7 m magasságban meghatározott karbonát csúcsok eltüntek, illetve mélyebbre húzódtak.

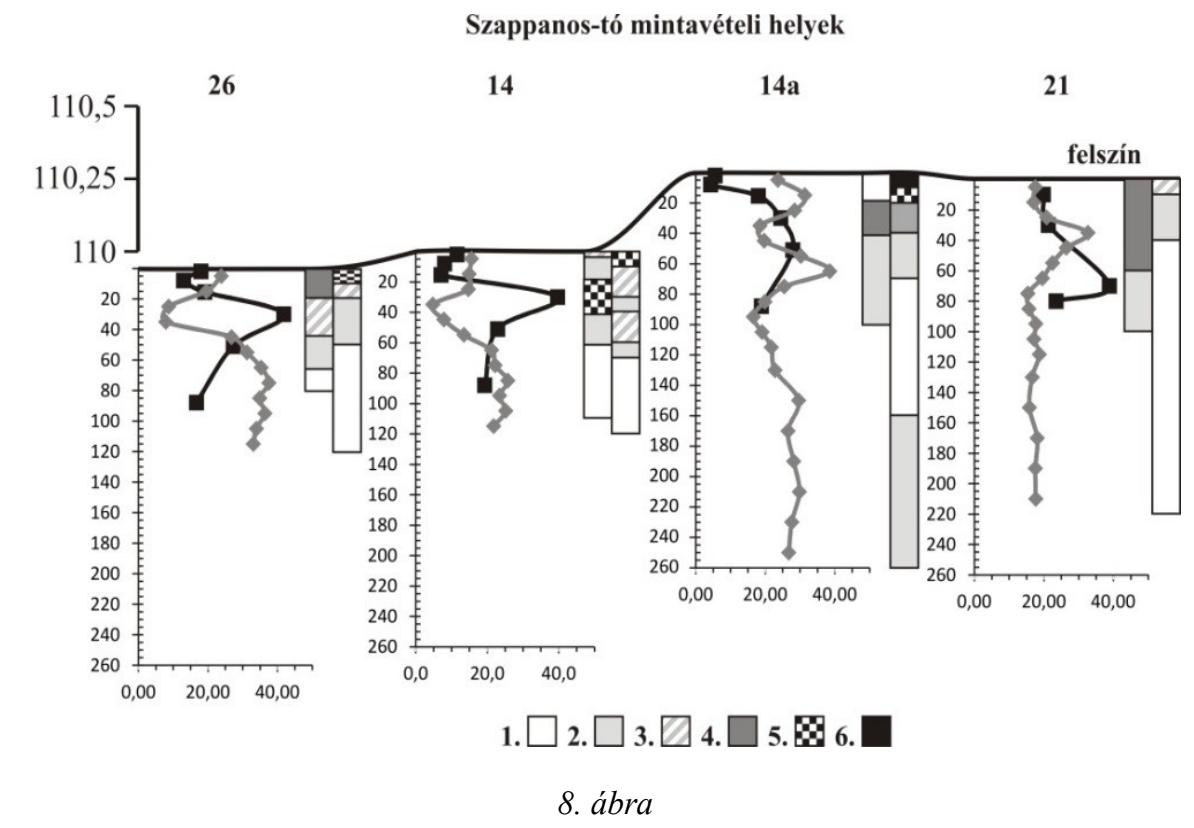

A karbonáttartalom és a textúra változása a tengerszintfeletti magasság alapján rendezett szelvényekben. A fekete vonalak és a bal oszlop az 1983-as, a szürke vonalak és a jobb oszlop a 2014-es felvételezés értékeit mutatják. A textúra kategóriák: 1. homok, 2. vályogos homok, 3. homokos vályog, 4. homokos agyagos vályog, 5. vályog, 6. agyagos vályog 
A jelenségre két alternatív magyarázat adható. Az egyik szerint a kilúgzás következtében a karbonátok mélyebbre mosódtak, illetve a megnövekedett növényi borítás/gyökértömeg miatt a savanyú rhizoszféra csökkentette a karbonáttartalmat. Ezek a folyamatok azonban rendszerint kis sebességüek (VAN DEN BERG et al., 2000; IOST et al., 2007), és még 31 év folyamán sem várható ekkora változás.

A másik lehetőség az, hogy a tómederben a felszínen kisebb karbonáttartalmú feltalaj halmozódott fel lehordás (erózió) miatt, a tóparton pedig lehordás következtében a korábbi mélyebb karbonát csúcs a felszínhez közelebb került. A ráhordás/lehordás ellenőrzéséhez a 8 . ábrán feltüntettük a fizikai féleség kategóriákat mindkét mintavétel alapján (1983: részletes szemcseösszetétel, 2014: Sik-féle higroszkóposság), de ezáltal sem jutottunk közelebb a megoldáshoz.

A ráhordásra utalnak LADÁNYI (2010) eredményei, aki ötven év folyamán nem talált változást a felszínalatti karbonáttartalomban egy illancsi szikes mélyedés alatt.

Ezeket a feltételezéseket azonban további vizsgálatokkal kell igazolni és fenntartásokkal kell kezelni amiatt is, mert a vizsgálati pontok lokalizációja nem volt nagyon pontos, hiszen egyik esetben sem találtuk meg az 1983-ban feltárt szelvénygödrök helyét. Valószínüsíthető az is, hogy a terület térbeli változékonysága a feltételezett hatások megnyilvánulását tompíthatja. További nehézséget jelen a két időpont eltérő mélységi mintázási rendszere: 1983-ban szelvénygödörben genetikai szintek alapján, 2014-ben fúrás egyenletes rétegkiosztással.

A talaj humusztartalma a feltalajban 1-2\%-ról 4-5,5\%-ra nőtt (2. táblázat), kivéve a tóparti 21-es pontot (ahol kétszeresére). A legnagyobb mértékű növekedést a 14a. pontnál tapasztaltuk, ott, ahol a sótartalom a legnagyobb csökkenést mutatta.

A terület földhasználatában is jelentős változás zajlott: az elmúlt évek folyamán már nagyobb részét kaszálják, de a legmélyebben fekvő 26. és 14. pontok környéke (ahol nádat is megfigyeltünk) rendszerint nincs kaszálás. Ehhez képest a Szappanos-tó 1983-as felvételezése alatt csak a magasabb térszínekről (21. pont) jegyezték fel, hogy kaszáló volt. A területen időről időre nagyobb magasságban is összegyülekezik a belvíz. A mintavétel időpontjában a 26 . pontnál $\mathrm{kb} .5 \mathrm{~cm}$ volt a vízborítás.

A talajtípusok és a növényzet változását - amihez hasonlót számos szerző leírt (pl. HoYK et al., 2009) - a mederből kifelé haladva összefoglalóan a 2. táblázat mutatja. Az 1983-ban jellemző sókedvelő, nagy sótartalmat is türő növényekhez képest 2014-re a kis talajsótartalmat kedvelő növények terjedtek el, teljesen beborítva a felszínt.

\section{Összefoglalás}

A Duna-Tisza közi hátságban az elmúlt évtizedekben jelentős változások zajlottak le a terület hidrológiai viszonyaiban történt változások miatt. A hátság egyik legérzékenyebb természeti képződményei a szikes tavak. Ezek állandóságához nem csupán megfelelő vízellátottság, de megfelelő mennyiségü és minőségủ oldható só is szükséges. A hátságban zajló regionális és lokális vízforgalom tér- és időbeli koncepcionális modellje alapján, a Szappanos-tó példáján számszerüen jellemeztük 
az elmúlt 31 év folyamán a talajok sótartalom-változását. Ehhez négy, 1983-ban már vizsgált mintapontban a talajvíz szintjét, összetételét és a talajt is elemeztük lehetőség szerint ugyanolyan módszerrel.

A területen a talajvízszint süllyedt és a felszíni vízborítás jelentősen csökkent, valamint csökkent a talajvíz sótartalma, lúgossága és nátriumtartalma. A talaj felszínközeli rétegeiben csökkent a sótartalom, a pH és a nátriumtartalom.

$\mathrm{A} \mathrm{CaCO}_{3}$-tartalom mélységi lefutási görbéi átrendeződtek, ebben a kilúgzás mellett a tómederben és a partján müködő ráhordás/lehordás is jelentős szerepet játszhatott.

A tómedret teljesen benőtték a növények, az 1983-ban jellemző sókedvelö, nagy sótartalmat is türő növényekhez képest 2014-re a kis talajsótartalmat kedvelő növények terjedtek el, teljesen beborítva a felszínt. Megnövekedett a talaj humusztartalma és kiterjedt a füvek kaszálása.

A szerzők köszönetüket fejezik ki a KEOP-7.9.0/12-2013-0011 projektnek a terepi és laboratóriumi tevékenység finanszírozásáért és az OTKA NN79835 projektnek a müszerpark és egyes adatok rendelkezésre bocsátásáért. Köszönjük Rakonczai Jánosnak hasznos tanácsait és Barna Gyöngyinek (TAKI) valamint Bolla Bencének (KNP) a terepen nyújtott segítséget.

Kulcsszavak: Duna-Tisza közi hátság, kilúgzás, Szappanos-tó, talajvízszint süllyedés, sófelhalmozódás

\section{Irodalom}

BAKACSI Zs., 2001. Kiskunsági alluviális síkság talajtani-domborzati sajátságainak térinformatikai alapú vizsgálata, különös tekintettel a feltételezett talajvízszintváltozásokra. Agrokémia és Talajtan. 50. (3-4) 371-382.

Biró, M., RÉvÉsz, A., MolnÁr, Zs. \& HorvÁTH, F., 2007. Regional habitat pattern of the Danube-Tisza interfluve in Hungary I. The landscape structure and habitat pattern; the fen and alkali vegetation, Acta Botanica Hungarica. 49. (3-4) 267303.

BIRÓ M., 2011. Változástérképek használata tíz év alatt bekövetkezett élőhelypusztulási tendenciák kimutatására a Kiskunsági-homokhátság területén. Tájökológiai Lapok 9. 357-374.

Biró, M., Szitár, K., Horváth, F., BAGI, I. \& MolnÁr, Zs., 2013. Detection of longterm landscape changes and trajectories in a Pannonian sand region: comparing land-cover and habitat-based approaches at two spatial scales. Community Ecology. 14. (2) 219-230.

Boros E. \& BIRÓ Cs., 1999. A Duna-Tisza közi szikes tavak ökológiai állapotváltozásai a XVIII-XX. századokban. Acta Biol. Debr. Oecol. Hung. 9. 81-105.

BuZETZKY Gy. \& Zsuffa I., 1979. A nemzeti park vízrajzi leírása. In: Nemzeti Park a Kiskunságban (Szerk.: TÓTH K.). Natura Kiadó. Budapest. 
CSERNI I. \& FÜLEKY Gy., 2008. A Duna-Tisza közi homokhátság talajainak vízgazdálkodása. In: Talajvédelem Különszám. (Szerk.: SIMON L.) 53-62. Talajvédelmi alapítvány. Budapest.

DöVÉNYI Z. (Szerk.), 2010. Magyarország kistájainak katasztere. MTA Földrajztudományi Kutatóintézet. Budapest.

ERDÉLYI M., 1979. A Magyar Medence hidrodinamikája. VITUKI Közlemények. 18.

FÉNYES, J. \& KUTI, L., 1987. Geological history of the ponds in the Kiskunság National Park. In: Holocene Enviroment in Hungary. Contribution of the INQUA Hungarian National Commitee to the XII-th INQUA Congress. (Eds.: PÉCSI, M., \& KoRDOS, L.) 101-111. MTA Földrajztudományi Kutatóintézet. Budapest.

FILEP Gy. \& FERENCZ G., 1999. Javaslat a magyarországi talajok szemcseösszetétel szerinti osztályozásának pontosítására. Agrokémia és Talajtan. 48. (3-4) 419-428.

HaRmati I., 2000. A vízrendezések hatása a Duna-völgy szikes talajaira. Agrokémia és Talajtan. 49. (3-4) 369-382.

Hoyk, E., GÁCSI, Zs. \& BuZÁs, I., 2007. The connection between afforestation and aridification on the sand ridges between river Danube and Tisza. Cereal Research Communications. 35. (2) 757-760.

Hoyk, E., BuZÁs, I. \& HüVely, A., 2009. Manifestation of environmental stress demonstrated by some landscape forming factors. Cereal Research Communications. 37. (Suppl. 1) 473-476.

IlACO, B. V. (Ed.), 1981. Agricultural Compendium. Elsevier. Amsterdam.

IOST, S., LANDGRAF, D. \& MAKESCHIN, F., 2007. Chemical soil properties of reclaimed marsh soil from Zhejiang Province PR China. Geoderma. 142. (3) 245-250.

KERÉK B., 2003. A talaj-alapkőzet-talajvíz rendszer agrogeológiai és környezetföldtani vizsgálata a Bugaci-mintaterületen. Doktori (PhD) értekezés. Debreceni Egyetem, Természettudományi Kar. Debrecen.

KoHÁN B., 2014. GIS-alapú vizsgálat a Duna-Tisza közi homokhátság szárazodásának témakörében. Doktori (PhD) értekezés. Eötvös Loránd Tudományegyetem, Természettudományi Kar. Budapest.

KovÁcs, D., TóTh, T. \& MARTh, P., 2006. Study of food chain element transport analogy: salinity/sodicity/alkalinity of Hungarian soils during a decade as shown by the national soil monitoring network. Cereal Research Communications. 34. (1) $231-234$

KovdA, V. A., vAN DEN BerG, C. \& HAGAN, R. M. (Eds.), 1973. Irrigation, drainage and salinity. In: International Source Book. Hutchinson/FAO/UNESCO

Kuti L., KerÉK B., Müller T. \& VATAi J., 2002a. Az Alföld agrogeológiaikörnyezetföldtani térképei. Földtani Közlöny. 132. (különszám) 299-309.

Kuti L., VATAi J., MÜller. T. \& KerÉK B., 2002b. A talajvíztükör mélységeinek változása a Duna-Tisza közi hátságon. Földtani Közlöny. 132. (különszám) 317-325.

LADÁNYI Zs., 2010. Tájváltozások értékelése a Duna-Tisza közi homokhátság egy környezet- és klímaérzékeny kistáján, az Illancson. PhD értekezés. Szegedi Tudományegyetem, Szeged.

LADÁNYI Zs., RAKONCZAI J. \& DEÁK J. Á., 2012. A belvízelvezető csatornák és a klímaváltozás hatása egy dél-Magyarországi szikes élőhelyre In: Kockázat - Konfliktus - Kihívás: A VI. Magyar Földrajzi Konferencia, a MERIEXWA nyitókonferencia és a Geográfus Doktoranduszok Országos Konferenciájának Tanulmánykö- 
A Duna-Tisza közi hátság szikes tavainak kilúgzási folyamatai a Szappanos-tó példáján 89

tete. (Szerk.: NYÁRI $\quad$ D.) 495-508. SZTE TTK, Természetföldrajzi és Geonformatkai Tanszék. Szeged.

MÁdlnÉ SzŐNYI, J., Simon, Sz., TÓTH, J. \& PoGÁCsÁs, Gy., 2005. Connection between surface and groundwaters in the case of Kelemen-lake and Kolon-lake. Általános Földtani Szemle. 30. 93-110.

MÁdlné SzŐNYI, J., TÓTH, J. \& PogÁCsÁs, Gy., 2008. Soil and wetland salinization in the framework of the Danube-Tisza Interfluve hydrogeologic type section. Central European Geology. 51. (3) 203-217.

MARGóczi K., RAKONCZAi J., BARNA Gy. \& MAJlÁTH I., 2009. Szikes növénytársulások összetételének vizsgálata és talajának hosszú távú vizsgálata a Szabadkígyósi pusztán. Crisicum 5. Körös-Maros Nemzeti Park, Szarvas. 71-83.

MolnÁR B., 1979. Kialakulása és földtani felépítése. In: Nemzeti Park a Kiskunságban. (Szerk.: TóтH K.) 64-73. Natura Kiadó. Budapest.

MolNÁR B., 1980. Hiperszalin tavi dolomitképződés a Duna-Tisza közén. Földtani Közlöny 110. (1) 45-64.

MolnÁR B., 1994. Víztározók létesítésének vízföldtani adottságai a Duna-Tisza közi hátságon Hidrológiai Közlöny. 74. (6) 341-352.

MolnÁR, B. \& KUTI, L., 1987. Geological Aspects of Nature Conservation in the Kiskunság National Park. In: Holocene Enviroment in Hungary. Contribution of the INQUA Hungarian National Commitee to the XII-th INQUA Congress, Budapest. (Eds.: PÉCSI, M. \& KoRdOS, L.) 87-93. MTA Földrajztudományi Kutatóintézet. Budapest.

PÁlfAI I., 1995. A Duna-Tisza közi hátság vízgazdálkodási problémái és megoldásuk lehetséges útjai. Vízügyi Közlemények. 76. (1-2) 144-164.

RAJKAI K., MolnÁR E. \& RÉDLY L-né., 1983. Előtanulmányok a Kiskunsági Nemzeti Park védett területei környezetvédelmi kezelési tervének talajtani megalapozásához. Agrokémia és Talajtan. 32. (3-4) 449-453.

Rakonczai, J., Bozsó, G., Margóczi, K., Barna, Gy. \& PÁl-Molnár, E., 2008. Modification of salt-affected soils and their vegetation under the influence of climate change at the steppe of Szabadkígyós (Hungary). Cereal Research Communications. 36. (5) 2047-2050.

SzALAI J., 2004. A hidrológiai közelmúlt sajátosságai a talajvízszintekben, Vízügyi Közlemények. 2004. (1-2) 155-166.

SzALAI J., 2012. Időjárási szélsőségek hatása a Duna-Tisza köze talajvízjárásának alakulására. In: A VI. Magyar Földrajzi Konferencia, a MERIEXWA nyitókonferencia és a Geográfus Doktoranduszok Országos Konferenciájának Tanulmánykötete, 2012. (Ed.: NYÁRI K.) Szegedi Tudományegyetem, Természeti Földrajzi és Geoinformatikai Tanszék. Szeged.

SzABOLCS I. \& JASSÓ F. 1961. A szikes talajok genetikus típusai és elterjedésük törvényszerüségei a Duna-Tisza közén. Agrokémia és Talajtan. 10. (2) 173-194.

Tо́тн, J., 2009. Gravitational systems of groundwater flow: theory, evaluation, utilization. Cambridge University Press. Cambridge.

Tóth, T., Balog, K., Szabó, A., PÁsztor, L., Jobbagy, E. G., Nosetto, M. D. \& GRIBOVSZKI, Z., 2014. Influence of lowland forests on subsurface salt accumulation in shallow groundwater areas. AoB Plants. 6. doi: 10.1093/aobpla/plu054. 
VAN DEN BerG, G. A. \& LOCh, J. P. G., 2000. Decalcification of soils subject to periodic waterlogging. European Journal of Soil Science. 51. (1) 27-33.

VÁRALlYAY, GY., 1993. Soils in the region between the rivers Danube and Tisza (Hungary). In: The flora of the Kiskunság National Park In the Danube-Tisza MidRegion of Hungary. (Eds.: SzujKÓ-LACZA, J. \& KovÁTS, D.) 1. 21-42. Budapest.

VÁrallyay Gy. et. al. 1983. A Kiskunsági Nemzeti Park Bócsa-Bugac buckavilága és a Homokpuszta területének termőhelyi viszonyai. Jelentés a KNP részére 1983ban végzett munkálatokról. MTA Talajtani és Agrokémiai Kutató Intézet. Budapest.

Érkezett: 2015. február 20. 
A Duna-Tisza közi hátság szikes tavainak kilúgzási folyamatai a Szappanos-tó példáján 91

\title{
Leaching processes in saline lakes on the sand ridge of the Danube-Tisza Interfluve: the case of Lake Szappanos
}

\author{
T. TÓTH, S. MOLNÁR, K. BALOG and Z. BAKACSI
}

Institute for Soil Sciences and Agricultural Chemistry, Centre for Agricultural Research, Hungarian Academy of Sciences, Budapest

\section{Summary}

In recent decades considerable changes have taken place on the sand ridge of the Danube-Tisza Interfluve due to shifts in the hydrological conditions of the area. Some of the most sensitive natural formations on the ridge are the saline lakes. If these are to function in an optimal manner, they require not only sufficient water, but also a satisfactory quantity and quality of salts.

Changes in soil salinity during the last 31 years were quantitatively characterised with a spatio-temporal conceptual model of the regional and local water cycle of the saline lakes, using Lake Szappanos as an example. Four points, previously sampled in 1983, were re-sampled and an analysis was made both of the groundwater level and composition and of the soil, using the same methods wherever possible.

The groundwater level of the area dropped and surface water cover shrank substantially, with an accompanying decrease in the salinity, alkalinity and sodicity of the groundwater. There was a decline in the salinity, $\mathrm{pH}$ and sodicity of the surface soil layers.

The depth distribution profiles of $\mathrm{CaCO}_{3}$ changed, due not only to leaching but also to sedimentation/runoff.

The lakebed is now completely covered by vegetation. In contrast to the halophytes and halotolerant species recorded in 1983, oligo-halophytes were found to cover the whole lakebed in 2014. There was an increase in soil organic matter content and grass is now mown on extensive areas.

Table 1. Summary of the processes shown in Figure 2, from the 1960 s to the present. (1) Parameter, process. (2) Changes in water quantity. (3) Changes in soil salinity in the neighbourhood of the lake. a) Winter precipitation quantity, b) Sub-surface runoff and recharge, c) Effect of the functioning channel, d) Evaporation, e) Lake water level, f) Soil groundwater level, g) Water permeability of the carbonate silt in the lakebed, h) Decrease, i) Drainage, j) Increase, k) Decrease, 1) Drying up, breaking up, becoming permeable. Note: *Changes in the water table are also affected by both deep water exploitation and the increase in groundwater uptake due to afforestation (KOHÁN, 2014), but these are not shown separately.

Table 2. Soil type, vegetation and humus content during the surveys in 1983 and 2014. (1) Sampling point. (2) Year. (3) Humus content, \%. A. Lakebed. B. Shore. a) Sodic solonchak/Sedge (Phragmites australis, Schoenoplectus lacustris); b) Solonchak/Suaeda maritima; c) Solonchak meadow soil covered by sand sheets/Puccinellia limosa; d) Meadow soil/Meadow; e) Meadow soil/Phragmites australis, Agrostis stolonifera, Glyceria maxima; f) Meadow soil/Festuca pseudovina, Bryophyta, Phragmites australis (sporadically); g) Meadow soil/Agrostis stolonifera, Alopecurus pratensis, 
Phragmites australis, Achillea asplenifolia; h) Meadow soil/Festuca pseudovina, Bryophyta, Achillea asplenifolia.

Figure 1. Geological section intersecting the Bócsa-Bugac area and lakes (MOLNÁR \& KUTI 1987) Legend: 1. Medium-grained shifting sands. 2. Small-grained shifting sands. 3. Fine-grained shifting sand. 4. Loess (1-4: Pleistocene). 5. Humus-rich, poorlygraded lake silt. 6. Carbonate silt (5-6: Holocene). 7. Peat (Pleistocene-Holocene). 8. Humus-containing layers on the surface.

Figure 2. Conceptual water cycle model for the vicinity of a saline lake on the ridge. Legend: A. Groundwater level in the 1960s. B. Present groundwater level. a) Lake water level in the 1960s, b) Present lake water level. (For numbered processes, see Table 1.)

Figure 3. Local material flow model of the lake, with a schematic indication of hydrological changes. Legend: A. Groundwater level after a rainy season. B. Groundwater level after recharge/runoff from the regional catchment area. C. Salt accumulation, salt exchange between groundwater and soil. F. Soil surface.

Figure 4. Location of the studied lake and sampling points. Changes in the groundwater level and in the salinity of the groundwater and soil, based on surveys of the same sample points between the lakebed and the shore in 1983 and 2014. A. Uncertainty in the measurements due to the mixing of groundwater and surface water in 2014.

Figure 5. $\mathrm{pH}$ of the groundwater at sample points located between the lakebed and the shore in 1983 and 2014.

Figure 6. Changes in the salinity (\%) of soil profiles arranged according to altitude (m above sea level, mASL). Black lines: 1983 data (measured), grey lines: 2014 data (calculated from measured EC values).

Figure 7. Changes in the $\mathrm{pH}$ of soil profiles arranged according to altitude (mASL). Black lines: 1983 data, grey lines: data calculated from measured EC in 2014.

Figure 8. Changes in the carbonate content and texture of soil profiles arranged according to altitude (mASL). Legend: Black lines and left-hand column: 1983 data, grey lines and right-hand column: 2014 data. Soil texture categories: 1. sand, 2. loamy sand, 3. sandy loam, 4. sandy clay loam, 5. loam, 6. clay loam. 